DOI: $10.17516 / 1997-1370-0786$

УДК 330.46

\title{
Impact of the Prospective Roundwood Export Ban on Russian Timber Production
}

\author{
Alina S. Stoilova* \\ Institute of Economics and Industrial Engineering \\ Siberian Branch of the Russian Academy of Sciences \\ Novosibirsk, Russian Federation
}

Received 31.05.2021, received in revised form 15.06.2021, accepted 29.06.2021

\begin{abstract}
Illegal timber harvesting and trafficking is one of the most important economic and environmental problems in the Russian Federation. Illegal logging leads to degradation of forests and a shortage of timber in wood industries. One of the measures to counter illegal logging is the ban on the export of raw wood, which will take effect on January 1, 2022. However, such a measure will lead not only to control over the circulation of illegal timber, but also to a number of economic consequences. The impact of the ban on the inland market can be assessed using the point sectoral model of the forestry complex (PSM-fc). The results of scenario calculations show that a ban on the export of raw materials can lead to a reduction in logging volumes and an increase in the share of products of deeper processing in exports.
\end{abstract}

Keywords: export of raw wood materials, timber industry, timber complex, industrial policy, forestry.

The study was funded by the Russian Science Foundation (project 19-18-00145). The original methodology for intersectoral interregional modeling underlying the point sectoral model of the forest complex was developed as part of the IEIE SB RAS research plan for 2021: Project 5.6.6.4 (0260-2021-0007).

Research area: economics.

Citation: Stoilova A. S. (2021) Impact of the prospective roundwood export ban on russian timber production. J. Sib. Fed. Univ. Humanit. Soc. Sci., 14(7), 1080-1091. DOI: 10.17516/1997-1370-0786.

(C) Siberian Federal University. All rights reserved

* Corresponding author E-mail address: stoylova.as@mail.ru 


\title{
Влияние перспективного запрета экспорта круглого леса на производство лесопродукции в России
}

\author{
A.С. Стойлова \\ Институт экономики и организачии \\ промышиенного производства СО РАН \\ Российская Федерачия, Новосибирск
}

\begin{abstract}
Аннотация. Незаконные рубки и оборот нелегальных лесоматериалов являются важными факторами экономических и экологических проблем в Российской Федерации. Нелегальные лесозаготовки приводят к деградации лесов и дефициту лесного сырья на деревообрабатывающих производствах. Одна из мер противодействия нелегальной вырубке леса - запрет экспорта необработанной древесины, который вступит в силу 1 января 2022 года. Однако такая мера приведет не только к контролю над оборотом нелегальной древесины, но и к ряду экономических последствий. Оценить влияние запрета на внутренний рынок можно с помощью точечной отраслевой модели лесного комплекса (ТОМ-лк). Результаты сценарных расчетов показывают, что запрет экспорта сырья может привести к сокращению объемов лесозаготовки и увеличению в экспорте доли продукции более глубокой переработки.
\end{abstract}

Ключевые слова: экспорт лесного сырья, лесная промышленность, лесной комплекс, промышленная политика, лесное хозяйство.

Исследование выполнено за счет гранта Российского научного фонда (проект № 1918-00145). Исходная методология межотраслевого межрегионального моделирования, лежащая в основе точечной отраслевой модели лесного комплекса, разработана в рамках плана НИР ИЭОПП СО РАН на 2021 год: Проект 5.6.6.4 (0260-2021-0007) «Инструменты, технологии и результаты анализа, моделирования и прогнозирования пространственного развития социально-экономической системы России и её отдельных территорий».

Научная специальность: 08.00.05 - экономика и управление народным хозяйством.

\section{Introduction}

There is a vast literature on the problems of the Russian forest sector, but only some of them are devoted to modeling (Gordeev, 2018; Glazyrina et al., 2015; Pyzhev, Zander, 2019; Pyzhev et al., 2020). Agent-based models allow to analyze intersectoral interactions (Gulin, Antonov, 2017), econometric models give insight on modeling correlations between regulations and sectoral economic activity (Antonova, 2018). Some of the models can describe the global, national or regional economy (Latta et al., 2013; Solberg, 2010; Buongiorno, 1996). Models describing individual sub-sectors of the forest complex are: global model of trade in forest products (Kallio et al., 1987), wood supply model, wood market valuation model (Adams et al., 1980), pulp and paper market model (Gilless et al., 1987). These models can provide a basis for different types of modifications - thus, models of individual regions and countries can be built (Trømborg, 2010; Ronnila, 1995; Kallio et al., 2004).

One of the most important problems of the forestry complex in the Russian Federation is illegal logging. In 2017, the volume of illegal logging amounted to $1.7 \mathrm{mln}$ cub. $\mathrm{m}$, in 2018$1.1 \mathrm{mln}$ cub. $\mathrm{m}$, in the first half of 2019-0.6 mln cub. $m$. Thus, the damage caused to forests is estimated at an average of 5.8 bil roubles every six months. The largest volume of illegal logging is traditionally observed in the Irkutsk 
oblast. In the first half of 2019, the volume of illegal logging there exceeded $0.3 \mathrm{mln}$ cub. $\mathrm{m}$, which is almost $60 \%$ of the volume of national illegal logging (Lesa Rossii, 2021). To tackle illegal logging, forest inspections, state information system accounting wood, and prohibitive policies are used. The recent decree banning the export of raw timber, which will take effect on January 1, 2022 (Postanovlenie Pravitel'stva Rossiiskoi Federatsii ...) is the latest and most discussed policy action of the public Russian authorities.

This paper uses a point model of the forest sector of the Russian Federation (PSM-fc), the stages of construction and scenario calculations, to analyze the effects of changes in the inland market for forest products after implementing new sectoral policies. Using the Optimization Interregional Intersectoral Model (OIIM) as a basis for informational coordination with a complex of modified models of the forestry complex, it is possible to study the features of the interaction of economic entities in conditions of limited resources, to make forecasts for the development of regions, sectors, and the national economy as a whole. Each model of the complex allows scenario calculations and economical interpretation of the obtained results. Informational coordination between models helps to transfer the existing relationships between sectors and regions of the national economic model into the sectoral model. Thus, the step-by-step transition from the national economic to the sectoral model leads to a gradual reduction of information that is excessive from the point of view of the forestry complex and the simultaneous detailing of related indicators.

\section{Statement of the problem}

Optimization Interregional Intersectoral Models (OIIM) are used as a tool for solving problems of forecasting and analyzing the functioning of sectoral systems of the national economy (Ershov, Ibragimov, \& Mel'nikova, 2007). Currently, there is a number of sectoral, regional and transport modifications of the OIIM used for scenario calculations based on the development strategies for the country, sectors and regions. The use of OIIM allows to build a system of interrelated optimization models with a more detailed description of a specific regional or sectoral structure. In specialized types of OIIM, there is a detailed specification of the correlations and activities of the selected economic entities, while the rest of the entities, excessive from the point of view of analysis and forecasting, are presented in the form of a «national economic background». Also, the OIIM in value terms can serve as the basis for qualitative modification and the foundation for building a hierarchy of predictive models with the transition to sectoral models of the production and transport type in natural terms.

This article is containing description of the point sectoral model of the forestry complex of the Russian Federation (PSM-fc), the stages of its construction and scenario calculations. The value added of this work lies in the possibility to use the data of PSM-fc to analyze the impact of the ban on the export of raw coniferous wood and valuable deciduous wood species on the inland market.

\section{Methods}

The basis for subsequent modifications was the OIIM-40, which describes 40 sectors in 8 regions in the base year 2016. This model was developed in the Laboratory for Modeling and Analysis of Economic Processes of the Institute of Economics and Industrial Engineering, Siberian Branch, Russian Academy of Sciences. OIIM-40 is a system of eight regional blocks, balance restrictions on production and distribution of products, labor resources, investment, the volume of exports and imports of products, and some limitations on individual variables as well. The workflow is summarized in Figure 1.

Regional blocks are related by three modes of transportation (railroad transport, pipeline transport and other transport) and by the conditions for leveling the consumption levels of the population (Fig. 2). The objective function of OIIM-40 is the maximum of the nonproduction consumption fund of the population as a whole in the country in the last year of the forecast period with the given parameters of its territorial structure. 


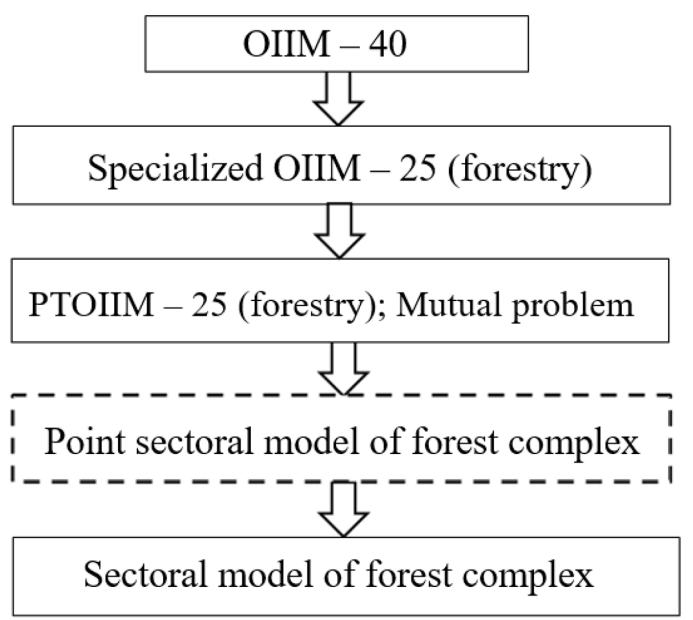

Fig. 1. The workflow for constructing a sectoral model of the forestry

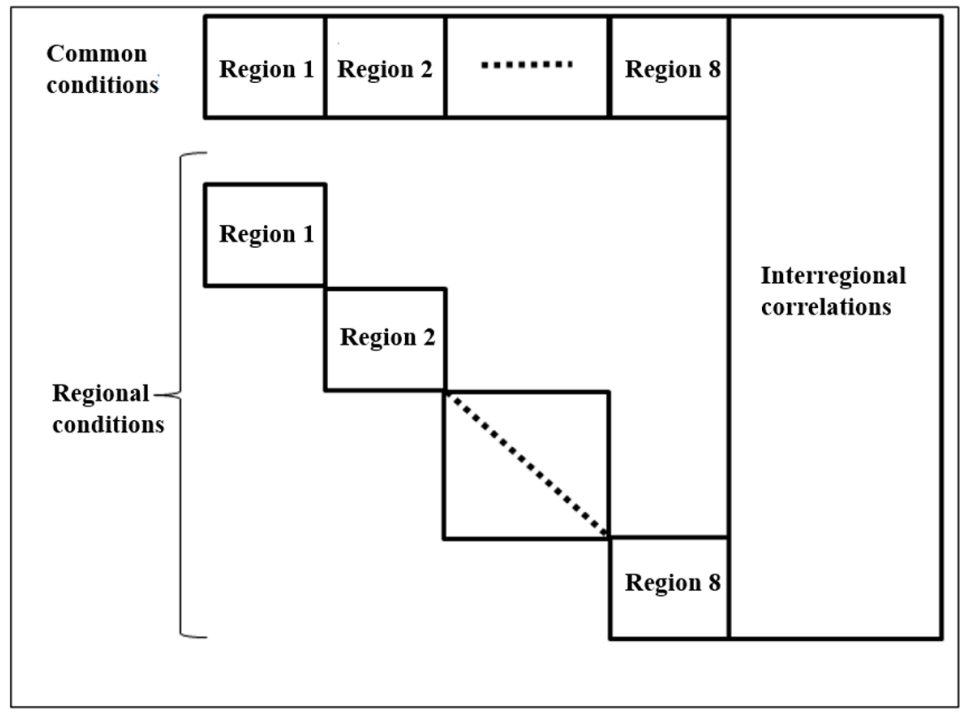

Fig. 2. Macrostructure OIIM-40

A rigorous mathematical description of the model can be found in (Granberg, Suslov, $\&$ Suspitsyn, 2007). To calculate and interpret the results of OIIM-40 problem, the properties of linear programming problems are used. The OIIM solution is one of the possible states of the economy at the end of the forecast period (2016-2030), when the optimum regional production volumes, interregional transportation of products, the use of labor resources, the interregional distribution of investments and the maximum of the non-productive consumption fund are achieved. The estimates obtained in solving the dual problem can be used to analyze the profitability of manufactured products, foreign trade operations, transportation between regions, labor costs, investments, etc. Stage I: building an OIIM-forest model. At the first stage, the branches of the forestry sector were detailed (Blam, Mashkina, 2018). These modifications were made in accordance with the All-Russian OKVED economic activity classifier. The sectors of the national economy that do not require aggregation include 
three types of transport sectors (railway, pipeline, and others), as well as mechanical engineering and construction sectors.

Few expert opinions and statistical information were used to fill the structure of production volumes. The resulting OIIM-25 model contained a description of twelve sectors of the forestry complex, but only three of them were the part of OIIM-40, as well. Table 1 shows the forestry sectors disaggregation structure.

A specialized OIIM-25 with detailed sectors of forestry complex is taken as a basis for the following transformations.

Stage II: construction of PTOIIM-25, mutual problem. At the second stage, OIIM-25 changed to OIIM of production and transport type (PTOIIM-25) using the theory of mutuality (Itskovich, 1976).

\section{Problem (I).}

Let us consider a problem with $(m+1)$ constraints.

The enterprise has at its disposal $m$ types of resources in the amount of $b_{1}, b_{2}, \ldots b_{m}$, respectively. These resources are used to produce $n$ types of products worth $c_{1}, c_{2}, \ldots c_{n}$, respectively. The norms of consumption $\alpha_{i j}(i=1, \ldots$, $m ; j=1, \ldots, n)$ are known for the production of a unit of each type of product. Moreover, the enterprise has a scarce resource $d_{j}(j=1, \ldots, n)$, the use of which is limited to some value $\alpha>0$. The production plan $x_{1}, x_{2}, \ldots x_{n}$, thus, is made from the condition of maximizing the total cost of production.

$$
\sum_{j=1}^{n} c_{j} x_{j} \rightarrow \max
$$

provided that the following resource constraints are applied:

$$
\begin{aligned}
& \sum_{j=1}^{n} d_{j} x_{j} \leq \alpha(v) ;(\text { estimate } v) ; \\
& \sum_{j=1}^{n} a_{i j} x_{j} \leq b_{i} \text { for } i=1, \ldots, m \text { (estimate }
\end{aligned}
$$
$\left.u_{i}\right)$.

Let us suppose that there is an optimal vector $\check{x}$.

Let $\beta=\sum_{j=1}^{n} c_{j} \check{x}_{j}$ and $P_{1}$ be the set of optimal vectors of the problem.

\section{Theorem 1.}

The dual problem (II) to problem (I) is the following.

It is required to determine the optimal system of dual estimates of the resources $v, u_{i}$, used for the production of goods, at which the total cost of resources will be the least.

Table 1. Structure of the sectors of the forestry complex in the initial and specialized OIIM

\begin{tabular}{|c|c|}
\hline \multirow{2}{*}{ OIIM-40 forest sectors } & OIIM25 forest sectors \\
\hline \multirow{2}{*}{ Hunting and forestry } & Logging \\
\hline \multirow{4}{*}{ Woodworking } & Hunting and Forestry \\
\cline { 2 - 2 } & Industrial wood \\
\cline { 2 - 2 } & Plywood \\
\cline { 2 - 2 } & Chipboard \\
\cline { 2 - 2 } & Fiberboard \\
\hline \multirow{4}{*}{ Pulp and paper } & Other \\
\cline { 2 - 2 } & Pulp \\
\cline { 2 - 2 } & Paper \\
\cline { 2 - 2 } & Cardboard \\
\hline Other & Other \\
\hline \multirow{2}{*}{ (don't belong to forestry complex) } & Furniture \\
\hline
\end{tabular}




$$
\left[a v+\sum_{i=1}^{m} b_{i} u_{i}\right] \rightarrow \min
$$

provided that the following constraints apply:

$$
\begin{aligned}
& v \geq 0 \\
& u_{i} \geq 0 \\
& v d_{j}+\sum_{i=1}^{m} a_{i j} u_{i} \geq c_{i} \text { (estimates } x_{j} \text { ) has an }
\end{aligned}
$$

optimal solution if, for given $b, c$ problem (I) has an optimal solution.

According to Theorem 1, the dual problem has a solution $v, u_{1}, u_{2}, \ldots u_{m}$. Let us formulate problem (III), which we call mutual to problem (I).

\section{Problem (III).}

It is required to determine the optimal production plan $y_{1}, y_{2}, \ldots y_{n}$, which is made up from the condition of minimizing the costs of a scarce resource $d_{j}(j=1, \ldots, n)$, with the total cost of resources used in the production of products bounded from below by $\beta$ value.

$$
\sum_{j=1}^{n} d_{j} y_{j} \rightarrow \min
$$

provided that the following constraints apply:

$$
\begin{aligned}
& y_{i} \geq 0 ; \\
& \sum_{j=1}^{n} a_{i j} y_{j} \leq b_{i}(1 \leq i \leq m)\left(\text { estimates } \eta_{i}\right) \\
& \sum_{j=1}^{n} c_{j} y_{j} \geq \beta(\text { estimate } \xi)
\end{aligned}
$$

It is assumed that the estimate $v$ is positive. Let $\beta$ be the value of the maximum profit under these conditions. Then the mutual problem is to minimize labor costs, provided that the profit is not less than $\beta$ and the remaining constraints of the original problem are satisfied.

Let us formulate a theorem that states that the solutions of problems (I) and (III) coincide.

\section{Theorem 2.}

If the estimate $\breve{v}$ of constraint (1) of problem (I) is positive, then problem (III) is solvable, and the set $P_{2}$ of optimal vectors of problem (III) coincides with the set $P_{1}$ of optimal vectors of problem (I).

Let us interpret this problem in relation to OIIM-25. A general restriction on the use of la- bor resources for the country as a whole was added to the existing balance constraints of the problem.

$$
\sum_{r}\left(\sum_{i} l_{i}^{r 0} x_{i}^{r 0}+\sum_{i} \Delta l_{i}^{r T} \Delta x_{i}^{r T}\right) \leq \sum_{r} T^{r}
$$

The following notations are used:

$l_{i}^{r 0}$ are the coefficients of labor costs per unit of output in the sector $i$ of the region $r$ in the last year of the period;

$\Delta l_{i}^{r T}$ are the coefficients of labor costs per unit of the volume of output growth in the sector $i$ in the region $r$ for the period;

$T^{r}$ are the restrictions on the number of labor resources in the region $r$ in the last year of the period;

$x_{i}^{r 0}$ are the volumes of output in the sector $i$ of the region $r$ received in the last year of the forecast period from the production facilities operating at the beginning of the period;

$\Delta x_{i}^{r T}$ are the volumes of production in the sector $i$ of region $r$ in the last year of the period at the facilities commissioned for the period.

This constraint gave a positive estimate $\check{v}$ and did not affect the solution of the problem, since it was limiting. For further transition to the mutual problem, the optimal value of the functional was fixed as the quantity $\beta$. All other constraints of the original problem remained unchanged. The dual problem is to minimize labor costs in the whole country (2). In this case, all conditions of Theorem 2 are satisfied, and therefore the solution of the mutual problem coincides with the solution of the original OIIM-25.

Changing the structure of OIIM-25. The modifications at the next stage of the research led to the fact that sectors that are not related to the forestry complex began to appear in the model in an indirect form. To achieve this, variables that were not related to the production of forest products and the use of labor resources were excluded from the balance constraints of the model. The evaluation of the second members of the balance constraints (the load on the forestry complex from other sectors of the national economy) and the transition from the value terms of OIIM to natural measurements, are made using additional calculations and statistical information (Fig. 3). Detailed in- 
formation about this transition can be found in (Blam, Mashkina, 2018).

Stage III: construction of a point sectoral model of the forest complex of the Russian Federation. The final stage of modeling assumed the transition to the industrial model of the forestry complex of production and transport type (PTM-fc), but this step required preliminary preparation and additional calculations. The list of necessary changes to obtain the final version of the model included:

- creation of an information block for reclamation and processing of raw materials;
- calculation of technological methods of production;

- expanding the set of sectors;

- recalculation of the information block of interregional transportation, export, import, use and growth of capacities (Fig. 4).

Due to the difficulties in preparing a significant amount of information, introducing an auxiliary point sectoral model of the forestry complex (PSM-fc) is necessary to proceed.

PSM-fc is a simplified modification of the sectoral model that describes the forestry complex of Russia as a whole, excluding interre-

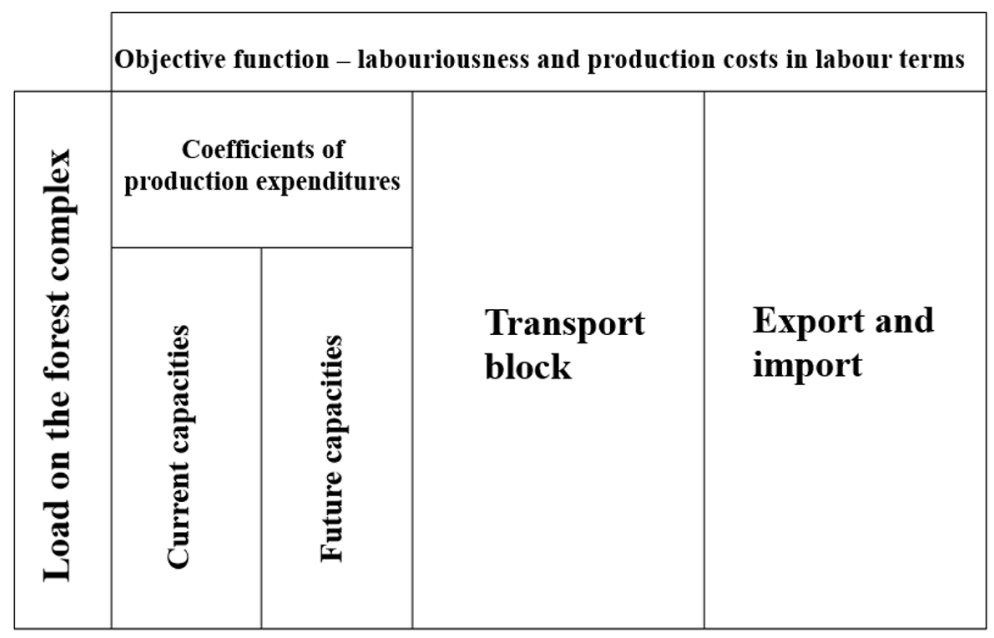

Fig. 3. Macrostructure of PTOIIM-25

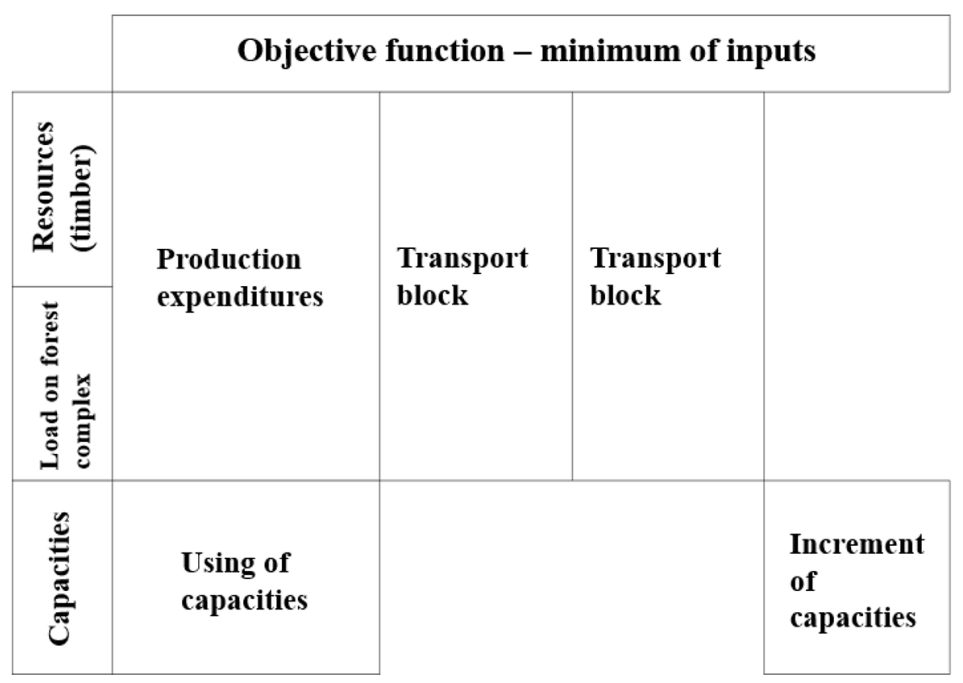

Fig. 4. Structure of the regional block in PTM-fc 
gional transportation. This model is filled with information from PTOIIM-25 and contains an even more detailed nomenclature and information blocks necessary for the transition to PTM-fc. When forming PSM-fc, in addition to information from PTOIIM-25, data from open sources were additionally used: Rosstat, academic literature, sectoral web-resources, etc. Table 2 shows a comparison of OIIM-25 nomenclature and sectoral models' nomenclature.

Using an PSM-fc, the optimal indicators of raw material reclamation, production, export and import were obtained for 2016. For scenario calculations, the following changes were made:
- The volume of commercial wood (coniferous) export has been reduced to 0 cub. $\mathrm{m}$.

- The volume of commercial wood (deciduous) export is reduced by $3 \%$. This value is obtained as the ratio of the volume of exported valuable varieties of deciduous wood (oak, beech, ash) to the total volume of exported deciduous wood. The data was taken from customs statistics for 2018.

- For calculations, the restriction on the maximum export volumes of products of deeper processing (industrial wood, plywood, chipboards, pulp, furniture) was increased.

A series of calculations was carried out on the basis of the data corrected. The load on the

Table 2. Comparison of the OIIM-25 forest nomenclature and sectoral models' nomenclature

\begin{tabular}{|c|c|}
\hline OIIM-25 forest nomenclature & Nomenclature of raw materials and forest products in the sectoral model \\
\hline Logging & $\begin{array}{l}\text { Commercial wood (coniferous), with a diameter of more than } 26 \mathrm{~cm} \\
\text { Commercial wood (coniferous), with a diameter of } 14-24 \mathrm{~cm} \\
\text { Commercial wood (deciduous), with a diameter of more than } 26 \mathrm{~cm} \\
\text { Commercial wood (deciduous), with a diameter of } 14-24 \mathrm{~cm} \\
\text { Low-quality wood } \\
\text { Wastepaper } \\
\text { Wood residue }\end{array}$ \\
\hline Hunting and forestry & $\begin{array}{l}\text { Reforestation } \\
\text { Forestry } \\
\text { Other forestry productions }\end{array}$ \\
\hline Industrial wood & $\begin{array}{l}\text { Industrial wood (coniferous) } \\
\text { Industrial wood (deciduous) }\end{array}$ \\
\hline Plywood & $\begin{array}{l}\text { Plywood (coniferous) } \\
\text { Plywood (deciduous) }\end{array}$ \\
\hline $\begin{array}{l}\text { Chipwood; } \\
\text { Fiberwood }\end{array}$ & $\begin{array}{l}\text { Chipwood } \\
\text { Fiberwood } \\
\text { MDF } \\
\text { OSB }\end{array}$ \\
\hline Other woodworking & $\begin{array}{l}\text { Pellet production } \\
\text { Timber house construction } \\
\text { Other woodwork productions }\end{array}$ \\
\hline Pulp & $\begin{array}{l}\text { Pulp (coniferous) } \\
\text { Pulp (deciduous) }\end{array}$ \\
\hline Paper & $\begin{array}{l}\text { Writings } \\
\text { News } \\
\text { Other paper }\end{array}$ \\
\hline Card board & Card board \\
\hline Other pulp and paper productions & Other pulp and paper productions \\
\hline \multirow[t]{2}{*}{ Furniture } & Furniture \\
\hline & Dendrochemistry \\
\hline
\end{tabular}


forestry complex from the side of the national economy (the second parts of the balance constraints) varied within 5-10\% of their average value. The production volumes, conditional optimal prices and export volumes were obtained.

As can be seen from the data given in Table 3, the shadow prices for large-sized timber are on average more than $20 \%$ higher than the similar prices presented by Rosstat.
This allows us to conclude that there is an insufficient level of supply of raw materials to producers, in particular, coniferous sawlogs and plywood logs. With a ban on the export of raw wood, the degree of shortage of commercial timber will decrease, however, with an increase in the production of products of deeper processing, the shortage of largesized timber may return to the previous level.

Table 3. Comparison of shadow prices based on the results of scenario calculations with the modelled basic solution prices and Rosstat prices (rub/unit)

\begin{tabular}{|l|c|c|c|c|c|c|}
\hline \multicolumn{1}{|c|}{ Type of resource } & Rosstat & Base & $\begin{array}{c}+0 \% \\
\text { exp. } \\
\text { value }\end{array}$ & $\begin{array}{c}+5 \% \\
\text { exp. } \\
\text { value }\end{array}$ & $\begin{array}{c}+10 \% \\
\text { exp. } \\
\text { value }\end{array}$ & $\begin{array}{c}+15 \% \\
\text { exp. } \\
\text { value }\end{array}$ \\
\hline $\begin{array}{l}\text { Commercial wood (coniferous), with a diameter of } \\
\text { more than } 26 \mathrm{~cm}\end{array}$ & $2,141.3$ & $2,520.5$ & $2,367.6$ & $2,362.7$ & $2,520.5$ & $2,520.5$ \\
\hline $\begin{array}{l}\text { Commercial wood (coniferous), with a diameter of } \\
14-24 \mathrm{~cm}\end{array}$ & 905.0 & $1,546.5$ & $1,406.2$ & $1,402.0$ & $1,546.0$ & $1,546.0$ \\
\hline $\begin{array}{l}\text { Commercial wood (deciduous), with a diameter of more } \\
\text { than } 26 \mathrm{~cm}\end{array}$ & $1,372.1$ & $2,045.0$ & $2,299.5$ & $2,307.6$ & $2,045.0$ & $2,045.0$ \\
\hline $\begin{array}{l}\text { Commercial wood (deciduous), with a diameter of 14- } \\
24 \mathrm{~cm}\end{array}$ & $1,984.9$ & $2,140.2$ & $2,016.9$ & $2,013.0$ & $2,140.2$ & $2,140.2$ \\
\hline
\end{tabular}

Table 4. Comparison of production indicators based on the results of scenario calculations and the modeled basic solution

\begin{tabular}{|l|c|c|c|c|c|}
\hline \multicolumn{1}{|c|}{ Name of product } & base & $\begin{array}{c}+0 \% \text { exp. } \\
\text { value }\end{array}$ & $\begin{array}{c}+5 \% \text { exp. } \\
\text { value }\end{array}$ & $\begin{array}{c}+10 \% \\
\text { exp. value }\end{array}$ & $\begin{array}{c}+15 \% \\
\text { exp. value }\end{array}$ \\
\hline Logging (mln cub. m) & 226.125 & 196.766 & 196.416 & 202.396 & 204.223 \\
\hline Forestry (bil roubles) & $\mathbf{7 . 2 6 1}$ & 6.968 & 6.964 & 7.024 & 7.042 \\
\hline Industrial wood (coniferous) (mln cub. m) & $\mathbf{3 8 . 3 4 4}$ & 37.854 & 38.245 & 39.741 & 40.617 \\
\hline Industrial wood (deciduous). (mln cub. m) & $\mathbf{5 . 4 3 0}$ & 5.124 & 5.123 & 5.218 & 5.521 \\
\hline Plywood (coniferous) (mln cub. m) & $\mathbf{3 . 5 5 9}$ & 2.381 & 2.305 & 2.380 & 2.430 \\
\hline Plywood (deciduous) (mln cub. m) & $\mathbf{1 . 2 9 8}$ & 1.278 & 1.223 & 1.251 & 1.259 \\
\hline Chipboard (mln cub. m) & $\mathbf{2 . 7 3 4}$ & 3.037 & 3.020 & 3.577 & 3.501 \\
\hline Fiberboard (mln cub. m) & $\mathbf{0 . 3 7 7}$ & 0.339 & 0.362 & 0.410 & 0.412 \\
\hline MDF (mln cub. m) & $\mathbf{2 . 0 2 4}$ & 1.747 & 1.847 & 2.333 & 2.156 \\
\hline OSB (mln cub. m) & $\mathbf{0 . 4 7 0}$ & 0.417 & 0.487 & 0.618 & 0.674 \\
\hline House construction (mln sq. m) & 2.477 & 2.647 & 2.493 & 2.572 & 2.586 \\
\hline Pellet (mln t) & $\mathbf{1 . 1 1 2}$ & 0.970 & 1.020 & 1.530 & 1.625 \\
\hline Pulp (coniferous) (mln t) & $\mathbf{6 . 6 7 5}$ & 6.675 & 5.689 & 6.351 & 6.454 \\
\hline Pulp (deciduous) (mln t) & $\mathbf{1 . 4 4 8}$ & 1.448 & 1.348 & 1.402 & 1.394 \\
\hline Paper (mln t) & $\mathbf{7 . 7 0 2}$ & 7.702 & 7.465 & 7.593 & 7.600 \\
\hline Cardboard (mln t) & $\mathbf{1 4 7 . 1 1 0}$ & 147.110 & 137.929 & 142.224 & 142.237 \\
\hline Furniture (bil roubles) & $\mathbf{1 5 4 . 2 1 9}$ & 102.139 & 92.512 & 97.352 & 97.346 \\
\hline
\end{tabular}


Table 5. Comparison of export volumes based on the results of scenario calculations and the modeled basic solution

\begin{tabular}{|l|c|c|c|c|c|}
\hline \multicolumn{1}{|c|}{ Name of product } & base & $\begin{array}{c}+0 \% \text { exp. } \\
\text { value }\end{array}$ & $\begin{array}{c}+5 \% \text { exp. } \\
\text { value }\end{array}$ & $\begin{array}{c}+10 \% \\
\text { exp. value }\end{array}$ & $\begin{array}{c}+15 \% \\
\text { exp. value }\end{array}$ \\
\hline $\begin{array}{l}\text { Commercial wood (coniferous), with a diameter of } \\
\text { more than 26 cm (mln cub. m) }\end{array}$ & $\mathbf{1 0 . 0 0 0}$ & 0.000 & 0.000 & 0.000 & 0.000 \\
\hline $\begin{array}{l}\text { Commercial wood (coniferous), with a diameter of } \\
14-24 \text { cm (mln cub. m) }\end{array}$ & $\mathbf{4 . 0 0 0}$ & 0.000 & 0.000 & 0.000 & 0.000 \\
\hline $\begin{array}{l}\text { Commercial wood (deciduous), with a diameter of } \\
\text { more than 26 cm (mln cub. m) }\end{array}$ & 3.568 & 3.104 & 2.755 & 3.011 & 2.957 \\
\hline $\begin{array}{l}\text { Commercial wood (deciduous), with a diameter of } \\
\text { 14-24 cm (mln cub. m) }\end{array}$ & $\mathbf{3 . 5 6 8}$ & 0.000 & 0.000 & 0.000 & 0.000 \\
\hline Industrial wood (coniferous) (mln cub. m) & $\mathbf{2 4 . 8 6 9}$ & 24.869 & 24.976 & 26.756 & 27.148 \\
\hline Industrial wood (deciduous). (mln cub. m) & $\mathbf{1 . 4 8 0}$ & 1.480 & 1.712 & 1.663 & 2.099 \\
\hline Plywood (coniferous) (mln cub. m) & $\mathbf{2 . 2 1 2}$ & 2.212 & 2.114 & 2.212 & 2.212 \\
\hline Plywood (deciduous) (mln cub. m) & $\mathbf{0 . 2 4 6}$ & 0.246 & 0.246 & 0.246 & 0.246 \\
\hline Chipboard (mln cub. m) & $\mathbf{1 . 6 1 0}$ & 1.610 & 1.673 & 2.195 & 2.252 \\
\hline Fiberboard (mln cub. m) & $\mathbf{0 . 1 5 6}$ & 0.156 & 0.220 & 0.222 & 0.246 \\
\hline MDF (mln cub. m) & $\mathbf{0 . 6 1 8}$ & 0.618 & 0.883 & 1.229 & 1.224 \\
\hline OSB (mln cub. m) & $\mathbf{0 . 0 6 8}$ & 0.068 & 0.223 & 0.276 & 0.450 \\
\hline House construction (mln sq. m) & 0.047 & 0.047 & 0.047 & 0.047 & 0.047 \\
\hline Pellet (mln t) & $\mathbf{1 . 0 7 6}$ & 1.076 & 1.293 & 1.494 & 1.764 \\
\hline Pulp (coniferous) (mln t) & $\mathbf{1 . 9 3 0}$ & 1.930 & 1.842 & 1.930 & 1.930 \\
\hline Pulp (deciduous) (mln t) & $\mathbf{0 . 2 1 4}$ & 0.214 & 0.214 & 0.214 & 0.214 \\
\hline Paper (mln t) & $\mathbf{3 . 3 7 6}$ & 3.376 & 3.329 & 3.376 & 3.376 \\
\hline Cardboard (mln t) & $\mathbf{0 . 2 7 5}$ & 0.275 & 0.275 & 0.275 & 0.275 \\
\hline Furniture (bil roubles) & $\mathbf{1 5 . 9 1 9}$ & 15.919 & 15.080 & 15.919 & 15.919 \\
\hline
\end{tabular}

It correlates with high level of illegal timber trade. The imposition of a ban on the export of raw wood will lead to an increase in the export of poorly processed timber, which will not solve the problem of illegal logging. The development of sectors processing not only high-quality wood, but also low-quality wood, as well as wood residue, can contribute to reducing the shortage of raw materials. There is a danger that the amount of felling waste will increase due to the lack of demand for low-quality timber.

The table above shows that with the ban on the export of raw timber, there is a decrease in the level of logging. To increase the production of wood products, it is necessary to build new facilities and to create an incentive in the form of external demand. But, since domestic products are of low quality, entering new markets will

\section{Conclusion}

The paper presents an approach to modeling and describes point sectoral model of the forest complex (PSM-fc), according to which system calculations were performed. With a complete ban on the export of coniferous raw timber and a partial ban on the export of deciduous raw timber, the volume of exports of products of the woodworking sector and the level of consumption of products of the forestry complex of the sectoral national economy varied.

According to the results of the data analysis, there was a decrease in the level of logging and an increase in the production of the main woodworking products (lumber, ply- 
wood and chipboards, etc.). This is due to the fact that the inland market was oversaturated with wood raw materials and did not have sufficient external demand for woodworking products.

Thus, the ban on the export of raw timber will significantly affect the inland market for forest products. An overabundance of raw materials will require an increase in the processing capacity of forest products and a significant increase in the volume of exports of products of deeper processing. In conditions of fierce competition for foreign markets, many manufacturers may face the impossibility of selling finished products due to their low quality. The ban will also affect enterprises engaged in timber harvesting. In the absence of demand for raw materials and the lack of their own processing facilities, many small and medium-sized enterprises may cease their activities.

\section{References}

Adams, D. M. and Haynes, R. W. (1980). The 1980 coniferous timber assessment market model: structure. Projections, and Policy Simulations Forest Science 26 a0001-a11.

Antonova, N.E. (2018). Evaluation of Economic Agents Responses of on Institutional Changes in the Region Forest Complex. In Prostranstvennaya Ekonomika [Spatial Economics], 4, 115-138. doi: 10.14530/ se.2018.4.115-138.

Blam, Iu. Sh., Mashkina, L.V. (2018). Postroenie ierarkhicheskogo nabora modelei: ot stoimostnoi OMMM k otraslevoi modeli v natural'nykh pokazateliakh [Building the hierarchical set of models: from OIIM in value terms to sectoral model in natural terms], In Mir economiki I upravleniia [The world of economics and management], 18(4), 126-139. doi: 10.25205/2542-0429-2018-18-4-126-139.

Buongiorno, J. (1996). Forest sector modeling: a synthesis of econometrics, mathematical programming, and system dynamics methods Int. J. Forecasting 12329.

Gilless, J. K. and Buongiorno, J. (1987). PAPYRUS: a model of the North American pulp and paper industry For. Sci. 33 a0001-a2.

Glazyrina, I.P., Yakovleva, K.A., Zhadina, K.A. (2015). Social and Economic Effectiveness of the Forest Use in the Russian Regions. In Regionalistika [Regionalistics], 2, 5-6, 18-33. doi: 10.14530/reg.2015.5-6.

Gordeev, R.V. (2018). Improving the Competitiveness of the Forest Products: New Lessons from the Trade Analysis In EKO, 8, 63-84. doi:10.30680/ECO0131-7652-2018-9-63-84.

Granberg, A.G., Suslov, V.I., Suspitsyn, S.A. (2007). Mnogoregional'nye sistemy: ekonomikomatematicheskoe issledovanie [Multi-regional systems: economic and mathematical research]. Novosibirsk, Sibirskoe Nauchnoe Izdatel'stvo, 371 p.

Gulin, K., Antonov, M. (2017). Theoretical Aspects of Agent-Based Modeling in the Development of the Forest Complex. Economic and Social Changes: Facts, Trends, Forecast, 6 (54). doi: 10.15838/ esc.2017.6.54.4.

Ershov, Ju.S., Ibragimov, N.M., Mel'nikova, L.V. (2007). Sovremennye postanovki prikladnykh mezhregional'nykh mezhotraslevykh modelei [Modern formulation of the engineering interregional intersectoral models], In Issledovaniia mnogo regional'nykh ekonomicheskikh sistem: opyt primeneniia optimizacionnykh mezhregional'nykh mezhotraslevykh sistem [Studies of multi-regional economic systems: experience in applying optimization interregional intersectoral systems]. Novosibirsk, IEIE SB RAS, 29-59.

Itskovich I. A. (1976). Analiz lineinykh ekonomiko-matematicheskikh modelei [Analysis of linear economic and mathematical models]. Novosibirsk, Nauka,190 p.

Latta, G.S., Sjølie, H.K., Solberg, B. (2013). A Review of Recent Developments and Applications of Partial Equilibrium Models of the Forest Sector. In Journal of Forest Economics, 19 (4), 350-60. doi: 10.1016/j.jfe.2013.06.006.

Lesa Rossii [Forests of Russia]. Available at: https://roslesinforg.ru/atlas (accessed 2 May 2021).

Kallio, M. et al. (1987). The Global Forest Sector: An Analytical Perspective (John Wiley \& Sons, Inc., UK) 
Kallio, A. M. I. et al. (2004). The global forest sector model EFI-GTM: the model structure. European Forest Institute EFI Technical Report 15

Postanovlenie Pravitel’stva Rossiiskoi Federatsii ot 18.03.2021 № 396 «O vnesenii izmenenii v nekotorye akty Pravitel'stva Rossiiskoi Federatsii I priznanii utrativshimi silu nekotorykh aktov I otdel'nykh polozhenii nekotorykh aktov Pravitel'stva Rossiiskoi Federatsii» [Decree of the Government of the Russian Federation of March 18, 2021 No. 396 «On Amendments to Certain Acts of the Government of the Russian Federation and the Recognition of Invalidation of Certain Acts and Certain Provisions of Certain Acts of the Government of the Russian Federation»] Available at: http://publication.pravo.gov.ru/Document/ View/0001202103190010?index $=1 \&$ rangeSize $=1$ (accessed 2 May 2021).

Pyzhev, A., Sharafutdinov, R., Borisova, I. (2020). Ecological and Economic Modelling of the Forestry Problems of Russia IOP Conf. Ser.: Mater. Sci. Eng. 753 082004. doi: 10.1088/1757-899X/753/8/082004

Pyzhev, A., Zander, E. (2019). Modeling of the regional forest sector to improve economic and legal relations in forest management. In Journal of Siberian Federal University. Humanities \& Social Sciences [Zhurnal Sibirskogo federal'nogo universiteta. Seriia: Gumanitarnye nauki], 12 (11), 2091-2096. doi: 10.17516/1997-1370-0515

Ronnila, M. (1995). Medium-term scenarios for the Finnish pulp and paper industry International Institute of Applied Systems Analysis WP 95-38

Solberg, B., Moiseyev, A., Kallio, A.M.I., Toppinen, A. (2010). Forest Sector Market Impacts of Changed Roundwood Export Tariffs and Investment Climate in Russia. In Forest Policy and Economics, 12, 1, 17-23. doi: 10.1016/j.forpol.2009.09.016.

Trømborg, E. and Solberg, B. (2010). Forest sector impacts of the increased use of wood in energy production in Norway Forest Pol. Econ. 1239. 